\title{
Pengaruh Pemberian Tepung Daun Senduduk (Melastoma malabathricum L.) dalam Ransum terhadap Fraksi Lipid Darah dan Persentase Berat Organ Dalam Ayam Buras
}

\author{
Effects of Senduduk (Melastoma malabathricum L.) Leaf Flour Inclusion in Ration on Blood \\ Lipid Fraction and Percentage of Internal Organ Weight in Buras Chicken
}

\author{
M. Dorisandi, Y. Fenita, dan E. Soetrisno
}

Jurusan Peternakan, Fakultas Pertanian, Universitas Bengkulu

Jl. WR. Supratman, Kandang Limun, Bengkulu 38371A

Corresponding e-mail : meisidorisandi031@gmail.com

\begin{abstract}
This study aimed to evaluate the effect of Senduduk leaf flour (Melastoma malabathricum L.) application in the ration on the blood lipid fraction and the weight of internal organs in domestic chicken. This research was conducted on May 30th, 2018 to July 10th, 2018 at the Commercial Zone and Animal Laboratory (CZAL) and Animal Husbandry Laboratory, Department of Animal Husbandry, Faculty of Agriculture, University of Bengkulu. The design used was a Completely Randomized Design (CRD). This study used 100 native chickens with 5 weeks of age consisting of 5 treatments and 4 replications, each of which consisted of 5 native chickens. The treatments were, PO: Control, P1: adding 1.5\% Senduduk leave, P2: adding 2.5\% Senduduk leave, P3: adding $3.5 \%$ Senduduk leave, P4: adding $4.5 \%$ Senduduk leave. The parameters measured in this study used a sample of 2010 -week-old chickens, were blood lipid fraction consisting of triglycerides, cholesterol, HDL (high-density lipoprotein), LDL (low-density lipoprotein), VLDL (very low-density lipoprotein), a comparison index of LDL with HDL, and weight of internal organs consisting of liver, heart, lymph, gizzard, intestinal weight, and intestinal length. The data obtained were analyzed by variance (ANOVA). Further testing utilized the Duncan Multiple Test (DMRT) Test. The results showed that the administration of Senduduk leaf flour (Melastoma malabathricum L.) in the ration had a very significant cholesterol levels, significant effect $(\mathrm{P}<0.05)$ on, LDL-c levels, atherogenic index levels, but not significantly different $(\mathrm{P}>0.05)$ on triglyceride levels, HDL levels, VLDL levels, and also not significantly different $(\mathrm{P}>0.05)$ to the percentage of heart, spleen, gizzard, intestine, and intestinal length.
\end{abstract}

Key words: leaf powder, buras chicken, blood lipid fraction, internal organ

\begin{abstract}
ABSTRAK
Penelitian ini bertujuan untuk mengevaluasi pengaruh pemberian tepung daun Senduduk (Melastoma malabathirium L.) dalam ransum terhadap fraksi lipid darah dan berat organ dalam pada ayam buras. Penelitian ini dilaksanakan pada tanggal 30 Mei 2018 sampai 10 Juli 2018 di Commercial Zone and Animal Laboratory (CZAL) dan Laboratorium Peternakan Jurusan Peternakan Fakultas Pertanian Universitas Bengkulu. Rancangan yang digunakan adalah Rancangan Acak Lengkap (RAL). Penelitian ini menggunakan 100 ekor ayam buras berumur 5 minggu, terdiri 5 perlakuan 4 ulangan, setiap ulangan terdiri 5 ekor ayam buras. Perlakuan tersebut, TO: Kontrol, T1: menggunakan 1,5\% daun Senduduk, T2: menggunakan 2,5\% daun Senduduk, T3: menggunakan 3,5\% daun Senduduk, T4: menggunakan 4,5\% daun Senduduk. Paramater yang diukur pada penelitian ini menggunakan sampel sebanyak 20 ekor ayam berumur 10 minggu yakni fraksi lipid darah terdiri trigliserida, kolestrol, HDL (high-density lipoprotein), LDL (low-density lipoprotein), VLDL (verry low- density lipoprotein), index perbandingan antara LDL dengan HDL, dan berat organ dalam terdiri berat liver, berat jantung, berat limfa, berat gizzard, berat usus, dan panjang usus. Data yang diperoleh dianalisis dengan sidik ragam (ANOVA). Uji lanjut menggunakan Uji Duncan's Multiple Range Test (DMRT). Hasil penelitian menunjukkan bahwa pemberian tepung daun Senduduk (Melastoma malabathricum) dalam ransum berpengaruh sangat nyata $(\mathrm{P}<0.01)$ terhadap kadar kolesterol, berpengaruh nyata $(\mathrm{P}<0.05)$ terhadap kadar LDL-c, kadar index aterogenik, tetapi tidak berbeda nyata $(\mathrm{P}>0.05)$ terhadap kadar trigliserida, kadar HDL-c, kadar VLDL, dan juga tidak berbeda nyata $(\mathrm{P}>0.05)$ terhadap persentase berat hati, jantung, limpa, gizzard, usus, dan panjang usus.
\end{abstract}

Kata Kunci: daun Senduduk, ayam buras, fraksi lipid darah, organ dalam 


\section{PENDAHULUAN}

Berdasarkan data statistik yang dikeluarkan oleh Direktorat Jenderal Peternakan dan Kesehatan Hewan tahun 2017, pada tahun 2016 konsumsi daging segar per kapita sebesar $5,110 \mathrm{~kg}$, atau meningkat sebesar $6,52 \%$ dari konsumsi tahun 2015 sebesar $4,797 \mathrm{~kg}$, dan konsumsi daging segar terbanyak adalah konsumsi daging ayam buras (Direktorat Jenderal Peternakan dan Kesehatan Hewan, 2017). Tingginya konsumsi ayam buras dikarenakan sebagian masyarakat di wilayah pedesaan memelihara ayam buras untuk memenuhi kebutuhan protein hewani mereka. Untuk meningkatkan produksi ayam buras perlunya manajemen pemeliharaan yang baik dan pemenuhan kebutuhan nutrisi dalam pakan yang diberikan. Selain itu, untuk tetap menjaga produktivitas ayam buras perlu pemberian antibiotik.

Keunggulan ayam kampung adalah rasa dagingnya yang khas, sehingga mempunyai pangsa pasar tersendiri dan bukan merupakan saingan bagi produk ayam ras. Besarnya pangsa pasar ayam kampung tercermin dari semakin banyaknya restoran/outlet/gerai yang menggunakan daging ayam kampung sebagai andalan (Priyanti et al., 2005). Ayam buras juga dapat menjadi sumber penghasilan atau tabungan hidup yang sewaktu- waktu dapat dijual untuk keperluan mendesak (Rasyid, 2002). Populasi yang cukup tinggi, secara nasional ayam buras turut berperan sebagai penyedia protein hewani bagi masyarakat. Terkait dengan hal tersebut pemerintah menempatkan posisi ayam buras sebagai komoditi utama dalam kebijaksanaan pembangunan peternakan di Indonesia (Direktorat Jenderal Peternakan, 2001).

Feed additive dalam pakan unggas umumnya digunakan untuk merangsang pertumbuhan dan memperbaiki konversi pakan (Bintang dan Jarmani, 2012). Penggunaan antibiotik mengalami penurunan dan dibeberapa negara penggunaan dilarang sebagai bahan additive dalam pakan (Yamin et al., 2009). Salah satu cara untuk mengantisipasi dilarangnya penggunaan antibiotik, sebaiknya mulai sekarang agar dipersiapkan alternatif lain yang akan digunakan sebagai pengganti antibiotik dan diharapkan pengganti antibiotik tersebut akan lebih mudah diperoleh, mudah diaplikasikan dan harganya pun dapat bersaing dibanding sebelumnya. Tentunya juga tidak menyebabkan terjadinya residu dan efek samping yang merugikan (Direktorat Pakan, 2014). Pada penelitian ini perlunya substitusi penggunaan antioksidan dan antibakteri alami, salah satunya adalah daun Senduduk.

Daun

Senduduk

(Melastoma

malabathricum L.) berpotensi sebagai antioksidan dan antibakteri sehingga dapat dijadikan sebagai antibiotik alami. Daun Senduduk mengandung tanin, flavonoid, steroid, saponin, dan glikosida yang berfungsi membunuh atau menghambat pertumbuhan mikroorganisme. Selain itu, daun Senduduk juga dapat digunakan sebagai obat penyembuh luka. Perendaman menggunaan ekstrak daun Senduduk pada konsentrasi $10-15 \%$ dapat direkomendasikan untuk penyimpanan daging ayam broiler pada suhu ruang (Afrianti, 2013).

Flavonoid dalam tubuh manusia yang berfungsi sebagai antioksidan sehingga sangat baik untuk pencegahan kanker. Flavonoid dapat mengurangi kadar kolesterol darah mencit yang mengalami hiperlipidemia dan mengurangi oksidasi kolesterol LDL yang memiliki peranan penting dalam proses arteriosklerosis. Flavonoid mengurangi sintesis kolesterol dengan cara menghambat aktivitas enzim acyl-CoA cholesterol acyl transferase (ACAT) pada sel HepG2 yang berperan dalam penurunan esterifikasi kolesterol pada usus dan hati, serta menghambat aktivitas enzim 3-hidroksi-3metil-glutarilCoA yang menyebabkan penghambatan sintesis kolesterol. Saponin dapat berikatan dengan asam empedu dan kolesterol (dari makanan) membentuk misel yang juga tidak dapat diserap oleh usus. Tannin di dalam tubuh akan berikatan dengan protein tubuh dan akan melapisi dinding usus, sehingga penyerapan lemak terhambat (Metwally et al., 2009; Terao, 
2008). Menurut Kurnia (2017) dalam penelitiannya membuktikan bahwa penggunaan tepung daun Senduduk (Melastoma malabathricum L.) sampai dengan taraf $4 \%$ tidak menurunkan peforma ayam kampung super. Namun belum meneliti lebih lanjut mengenai fraksi lipid darah dan persentase berat organ dalam.

Belum adanya informasi tentang fraksi lipid darah dan persentase organ dalam dengan pemberian tepung daun Senduduk (Melastoma malabathricum L.) untuk mengevaluasi pengaruh pemberian tepung daun Senduduk (Melastoma malabathricum L.) terhadap fraksi lipid darah dilihat dari kadar kolesterol, kadar trigliserida, kadar HDL- c (Hight-density lipoprotein cholestrol), kadar LDL- c (Low-density lipoprotein cholestrol), kadar VLDL- c (Verry-Low-density lipoprotein cholestrol), dan Index aterogenik, pada persentase berat organ dalam meliputi hati, jantung, limfa, gizzard dan usus serta mengukur panjang usus ayam buras, sehingga perlu dilakukan penelitian dilihat dari fraksi lipid darah dan persentase berat organ dalam dari perbandingan mengenai perbedaan antara yang diberikan daun Senduduk dengan yang tidak diberikan daun Senduduk.

\section{MATERI DAN METODE}

Penelitian ini dilaksanakan pada tanggal 30 Mei 2018 sampai 10 Juli 2018 di Commercial Zone and Animal Laboratory (CZAL) dan Laboratorium Peternakan Jurusan Peternakan Fakultas Pertanian Universitas Bengkulu.

Peralatan yang digunakan dalam penelitian ini adalah timbangan, tempat ransum, tempat minum, terpal, alat tulis, kandang, jarum suntik ukuran $3 \mathrm{ml}$, tabung anti koagulan, dan penggilingan atau blender. Bahan yang digunakan pada penelitian ini adalah 100 ekor ayam buras dari CV. Kuda Hitam Perkasa, daun Senduduk (Melostoma malabathricum L.), jagung giling, dedak halus, konsentrat pedaging, top mix, dan mineral mix.

Penelitian ini menggunakan Rancangan Acak Lengkap (RAL) dalam 5 perlakuan dengan 4 ulangan dan setiap ulangan berisi 5 ekor yang ditempatkan secara acak pada kandang sistem koloni. Total ayam yang digunakan sebanyak 100 ekor ayam buras. Perlakuan dibedakan berdasarkan level pemberian tepung daun Senduduk (Melastoma malabathricum L.) yang digunakan, yaitu:

T0: Pemberian 0\% Tepung Daun Senduduk.

T1: Pemberian 1,5\% Tepung Daun

Senduduk.

T2: Pemberian 2,5\% Tepung Daun

Senduduk.

T3: Pemberian 3,5\% Tepung Daun

Senduduk.

T4: Pemberian 4,5\% Tepung Daun

Senduduk.

\section{Pembuatan Tepung Daun Senduduk}

Daun Senduduk yang telah dipetik diletakan di atas jaring untuk dikeringanginkan. Pengeringan dilakukan dengan cara menjemur daun diatas jaring dan dikering- anginkan di dalam ruangan selama lebih kurang 3-4 hari. Pengeringan tidak dilakukkan di bawah sinar matahri langsung karena dikhawatirkan dapat merusak kandungan nutrisi yang ada dalam daun Senduduk. Daun yang telah kering kemudian digiling dan dianalisis proksimat.

\section{Persiapan Kandang}

Kandang dipersiapkan dengan cara sanitasi dan sterilisasi kandang. Setelah kandang bersih dan steril maka dilakukan pembersihan tempat pakan dan tempat minum. Selanjutnya, kandang yang telah siap digunakan kemudian dimasukkan ke brooder dan brooding ring, menyiapkan susunan ransum yang akan digunakan, serta menyiapkan segala kebutuhan kandang yang diperlukan dalam penelitian. Kandungan gizi dan komposisi bahan pakan penelitian disajikan pada Tabel 1 dan 2 berikut. : 
Tabel 1. Kandungan gizi bahan penyusun ransum

\begin{tabular}{lcccccc}
\hline Bahan pakan & $\begin{array}{c}\text { Protein } \\
\text { Kasar }(\%)\end{array}$ & $\begin{array}{c}\text { Lemak } \\
\text { Kasar }(\%)\end{array}$ & $\begin{array}{c}\text { Serat Kasar } \\
(\%)\end{array}$ & Ca (\%) & P (\%) & $\begin{array}{c}\text { ME } \\
(\mathrm{kkal} / \mathrm{kg})\end{array}$ \\
\hline Dedak $^{\text {a) }}$ & 8,5 & 4,2 & 1,7 & 0,2 & 1,0 & 1810 \\
Jagung kuning $^{\text {a) }}$ & 8,9 & 4 & 2,2 & 0,02 & 0,23 & 3321 \\
KBR $^{\text {b) }}$ & 40 & 6,3 & 4 & 2,75 & 1,45 & 2955 \\
Mineral mix $^{\text {TDS }}$ & - & - & - & 32,5 & 10 & - \\
\hline () & 10,24 & 1,36 & 17,52 & 2,44 & 0,19 & $2975,15^{\mathrm{d}}$
\end{tabular}

Sumber: $\quad$ a) Hartadi et al. (2005); b) Label Konsentrat Broiler (PT. Japfa Comfeed); c) Laboratorium Politeknik Pertanian Negeri Payakumbuh (2017)

Tabel 2. Komposisi bahan pakan penelitian

\begin{tabular}{lccccc}
\hline \multirow{2}{*}{ Bahan pakan } & \multicolumn{5}{c}{ Perlakuan } \\
\cline { 2 - 6 } & $\mathrm{T} 0$ & $\mathrm{~T} 1$ & $\mathrm{~T} 2$ & $\mathrm{~T} 3$ & $\mathrm{~T} 4$ \\
\hline Jagung Giling (\%) & 50 & 50 & 50 & 50 & 50 \\
Dedak (\%) & 18 & 17,5 & 16,5 & 15,5 & 14,5 \\
Konsentrat broiler (\%) & 30 & 30 & 30 & 30 & 30 \\
Mineral mix (\%) & 1 & 1 & 1 & 1 & 1 \\
Top mix (\%) & 1 & 0 & 0 & 0 & 0 \\
TDS (\%) & 0 & 1,5 & 2,5 & 3,5 & 4,5 \\
Total (gram) & 100 & 100 & 100 & 100 & 100 \\
\hline Kandungan Nutrisi & \multicolumn{5}{c}{} \\
\hline Protein (\%) & 17,98 & 18.09 & 18.11 & 18.13 & 18.14 \\
ME (kkal/kg) & 2872.80 & 2916.25 & 2933.15 & 2950.05 & 2966.95 \\
Ca (\%) & 1.20 & 1.23 & 1.28 & 1.28 & 1.30 \\
P (\%) & 0.83 & 0.83 & 0.82 & 0.81 & 0.80 \\
SK (\%) & 2.61 & 2.86 & 3.02 & 3.18 & 3.33 \\
\hline
\end{tabular}

Penelitian ini menggunakan 100 ekor ayam buras yang berumur 5 minggu dengan lama pemeliharaan selama 5 minggu. Pakan yang digunakan mengandung berbagai level Tepung Daun Senduduk (TDS); 0\%, 1,5\%, $2,5 \%, 3,5 \%$ dan $4,5 \%$, dengan PK $18 \%$ dan ME $2900 \mathrm{kkal} / \mathrm{kg}$.

\section{Fraksi Lipid Darah}

Pada penghitungan fraksi lipid darah sampel yang digunakan sebanyak 20 ekor pada ayam berumur 10 minggu, dimana 20 sampel ini berasal dari 5 perlakuan dan masing-masing perlakuan diambil 4 ulangan, kemudian darah diambil dari bagian bawah sayap, sebelumnya daerah tersebut dibersihkan dari bulu, dicuci atau dilap dengan kapas yang dibasahi alkohol. Sampel darah diambil dengan menggunakan jarum suntik ukuran $3 \mathrm{ml}$ dan dimasukkan ke dalam tabung yang mempunyai anti koagulan. Fraksi lipid darah diukur dengan menggunakan tabung yang mempunyai antikoagulan yang di sentivius pada kecepatan $3000 \mathrm{rpm}$. Serum pada darah kemudian dianalisa kadar kolestrol, kadar trigliserida dan LDL-c (Low-density lipoprotein cholestrol) dan HDL- c (Hightdensity lipoprotein cholestrol). Kadar kolestrol dan kadar LDL-c diukur dengan menggunakan metode Kulkami (2006) dan kadar trigliserida diukur dengan metode Fossati dan Prencipe (1982). Analisis fraksi lipid darah (Kolesterol, HDL, dan LDL) dilakukan di laboratorium Kimia Farma. VLDL-c dihitung dengan menggunakan rumus sebagai berikut:

$$
\text { VLDL-c }=\text { kolesterol }-(\text { HDL-c }+ \text { LDL-c) }
$$

Untuk memprediksi risiko kejadian aterosklerosis, indeks aterogenik dihitung dengan persamaan berikut:

Atherogenic index: $\frac{\text { Total kolesterol }-\mathrm{HDL}-\mathrm{c}}{H D L-c}$ 


\section{Persentase Berat Organ Dalam}

Pada penghitungan persentase berat organ dalam sampel yang digunakan sebanyak 20 ekor pada ayam berumur 10 minggu, dimana 20 sampel ini berasal dari 5 perlakuan dan masing-masing perlakuan diambil 4 ulangan, kemudian 20 sampel ayam ini disembelih dan di bersihkan dari bulu, kemudian dihitung presentasi organ dalam. Persentase berat organ dalam meliputi hati, jantung, limfa, gizzard dan usus serta mengukur panjang usus dengan menggunakan rumus perhitungan sebagai berikut:

Persentase Berat Hati: $\frac{\text { Berat liver }}{\text { Berat hidup }}$ x 100\% Persentase Berat Jantung: $\frac{\text { Berat jantung }}{\text { Berat hidup }} \times 100 \%$ Persentase Berat Limfa: $\frac{\text { Berat limfa }}{\text { Berat hidup }}$ x 100\% Persentase Berat Gizzard: $\frac{\text { Berat gizzard }}{\text { Berat hidup }} \times 100 \%$ Persentase Berat Usus: $\frac{\text { Berat Usus }}{\text { Berat hidup }}$ x 100\%

Panjang usus diukur dengan menggunakan penggaris dengan satuan Centrimetre $(\mathrm{cm})$.

Hasil percobaan dianalisis dengan ANOVA dan apabila terdapat perbedaan dilakukan dilanjutkan dengan uji Duncan's Multiple Range Test (DMRT).

\section{HASIL DAN PEMBAHASAN}

Hasil perhitungan fraksi lipid darah (kolesterol, trigliserida, LDL, HDL, VLDL, Index aterogenik) pada masing-masing perlakuan selama penelitian dapat dilihat pada Tabel 3 .

\section{Kadar Kolesterol}

Hasil analisis sidik ragam menunjukkan bahwa pemberian tepung daun Senduduk (Melastoma malabathricum L.) dalam ransum berpengaruh sangat nyata $(\mathrm{P}<0.01)$ terhadap kadar kolesterol. Hasil uji lanjut menunjukkan $\mathrm{T} 0$ berbeda nyata $(\mathrm{P}<0.05)$ dengan $\mathrm{T} 1, \mathrm{~T} 2, \mathrm{~T} 3$, dan $\mathrm{T} 4$. Semakin besar pemberian tepung daun Senduduk (Melastoma malabathricum L.) dalam ransum memberikan kadar kolesterol darah semakin turun. Rataan kadar kolesterol darah pada perlakuan T0 sampai T4 berkisar antara $(113,25 \mathrm{mg} / \mathrm{dl}-127,75 \mathrm{mg} / \mathrm{dl})$. Pada perlakuan T0 tanpa menggunakan tepung daun Senduduk (Melastoma malabathricum L.) menunjukkan kadar kolesterol darah yang tinggi yakni sebesar 127,75 mg/dl. Perlakuan T1 terjadi penurunan sebesar $6,2 \%$ yakni dengan kadar kolesterol sebesar 119,75 $\mathrm{mg} / \mathrm{dl}$. Pada perlakuan T2 terjadi penurunan sebesar 1,6\% dengan kadar kolesterol sebesar $117,75 \mathrm{mg} / \mathrm{dl}$.

Tabel 3. Fraksi lipid darah ayam buras dengan pemberian tepung daun Senduduk (Melastoma malabathricum L.)

\begin{tabular}{ccccccc}
\hline \multirow{2}{*}{$\begin{array}{c}\text { Parameter } \\
(\mathrm{mg} / \mathrm{dl})\end{array}$} & $\mathrm{T} 0$ & $\mathrm{~T} 1$ & $\mathrm{~T} 2$ & $\mathrm{~T} 3$ & $\mathrm{~T}$ & \\
\cline { 2 - 6 } Ket. \\
\hline Kolesterol & $127,75 \pm 3,095^{\mathrm{b}}$ & $119,75 \pm 7,588^{\mathrm{a}}$ & $117,75 \pm 2,362^{\mathrm{a}}$ & $113,75 \pm 3,403^{\mathrm{a}}$ & $113,25 \pm 1,892^{\mathrm{a}}$ & $* *$ \\
Trigliserida & $53,75 \pm 6,55$ & $52,00 \pm 5,35$ & $52,25 \pm 5,12$ & $51,00 \pm 3,74$ & $47,00 \pm 5,13$ & $\mathrm{~ns}$ \\
LDL & $46,75 \pm 6,238^{\mathrm{b}}$ & $41,25 \pm 3,593^{\mathrm{ab}}$ & $39,75 \pm 3,095^{\mathrm{a}}$ & $36,5 \pm 3,109^{\mathrm{a}}$ & $37,25 \pm 3,862^{\mathrm{a}}$ & $*$ \\
HDL & $56,00 \pm 2,943$ & $59,5 \pm 1,732$ & $59,5 \pm 2,645$ & $58,75 \pm 0,957$ & $56,25 \pm 2,595$ & $\mathrm{~ns}$ \\
VLDL & $25,00 \pm 8,869$ & $19,00 \pm 2,943$ & $18,50 \pm 3,696$ & $18,50 \pm 1,290$ & $19,75 \pm 1,290$ & $\mathrm{~ns}$ \\
Index & $1,29 \pm 0,12^{\mathrm{b}}$ & $1,01 \pm 0,08^{\mathrm{a}}$ & $0,98 \pm 0,06^{\mathrm{a}}$ & $0,94 \pm 0,09^{\mathrm{a}}$ & $1,02 \pm 0,02^{\mathrm{a}}$ & $*$ \\
Aterogenik & \multicolumn{2}{c}{ * } & & \\
\hline Keterangan: T0: Pemberian 0\% Tepung Daun Senduduk; T1: Pemberian 1,5\% Tepung Daun Senduduk; & T2:Pemberian 2,5\% Tepung Daun Senduduk; T3: Pemberian 3,5\% Tepung Daun Senduduk; T4: \\
& Pemberian 4,5\% Tepung Daun Senduduk; ns: non signifikan; **: sangat signifikan; *: signifikan
\end{tabular}


Pada perlakuan T3 terjadi penurunan sebesar 3,3\% dengan kadar kolesterol sebesar $113,75 \mathrm{mg} / \mathrm{dl}$. Pada perlakuan T4 terjadi penurunan sebesar 4,3\% dengan kadar kolesterol sebesar 113,25 mg/dl, perlakuan kadar kolesterol darah yang terkecil terdapat pada perlakuan ke empat (T4) yakni dengan menggunakan tepung daun Senduduk dengan level 4,5\%. Hal ini menunjukkan bahwa pemberian tepung daun Senduduk (Melastoma malabathricum L.) memberikan respon positif.

Menurut Metwally et al. (2009) flavonoid yang terdapat pada daun Senduduk (Melastoma malabathricum L.) mengurangi sintesis kolesterol dengan cara menghambat aktivitas enzim acyl-CoA cholesterol acyl transferase (ACAT) pada sel HepG2 yang berperan dalam penurunan esterifikasi kolesterol pada usus dan hati, serta menghambat aktivitas enzim 3-hidroksi-3meti-glutaril-CoA yang menyebabkan penghambatan sintesis kolesterol. Semakin besar pemberian tepung daun Senduduk (Melastoma malabathricum L.) dalam ransum memberikan kadar kolesterol dalam darah semakin turun.

\section{Kadar Trigliserida}

Hasil analisis sidik ragam menunjukkan bahwa pemberian tepung daun Senduduk (Melastoma malabathricum L.) dalam ransum berpengaruh tidak nyata $(\mathrm{P}>0.05)$ terhadap kadar trigliserida ayam buras. Rataan kadar trigliserida darah ayam buras yaitu T0, T1, T2, T3 dan T4 berturutturut sebesar 53,75 mg/dl, 52,00 mg/dl, 52,25 $\mathrm{mg} / \mathrm{dl}, \quad 51,00 \mathrm{mg} / \mathrm{dl}, \quad 47,00 \mathrm{mg} / \mathrm{dl}$. Hasil penelitian ini didukung oleh pernyataan Santoso et al. (2004) menyatakan bahwa kadar normal trigliserida yaitu 19,09 mg/dl $150 \mathrm{mg} / \mathrm{dl}$. Semakin turun kadar trigliserida maka semakin baik. Hal ini menunjukkan bahwa pemberian tepung daun Senduduk (Melastoma malabathricum L.) dapat menurunkan kadar trigliserida darah ayam buras, tetapi masih dalam kisaran normal.

Menurut Santoso dan Piliang (2004) umur ayam mempengaruhi kandungan trigliserida di dalam serum darah. Semakin tinggi umur maka kandungan trigliseridanya semakin meningkat. Umur ayam pada pengambilan sampel darah penelitian ini pada umur 10 minggu sehingga kadar trigliserida masih kisaran rendah.

\section{Kadar LDL-c (Low-density lipoprotein cholestrol)}

Hasil analisis sidik ragam menunjukkan bahwa pemberian tepung daun Senduduk (Melastoma malabathricum L.) dalam ransum berpengaruh nyata $(\mathrm{P}<0.05)$ terhadap kadar LDL-c. Hasil uji lanjut menunjukkan $\mathrm{T} 0$ tidak berbeda nyata dengan $\mathrm{T} 1$, tetapi berbeda nyata dengan T2, T3, dan T4. Rataan kadar LDL darah pada perlakuan T0 sampai T4 berkisar antara $(36,50 \mathrm{mg} / \mathrm{dl}-$ $46,75 \mathrm{mg} / \mathrm{dl})$. Pada perlakuan T0 tanpa menggunakan tepung daun Senduduk (Melastoma malabathricum L.) menunjukkan kadar LDL darah yang tinggi yakni sebesar $46,75 \mathrm{mg} / \mathrm{d} 1$. Perlakuan T1 terjadi penurunan sebesar $11,7 \%$ yakni dengan kadar LDL sebesar 41,25 mg/dl. Pada perlakuan T2 terjadi penurunan sebesar 3,6\% dengan kadar LDL sebesar 39,75 mg/dl. Pada perlakuan T3 terjadi penurunan sebesar $8,1 \%$ dengan kadar LDL sebesar 36,50 mg/dl, perlakuan kadar LDL darah yang terkecil terdapat pada perlakuan ketiga (T3) yakni dengan menggunakan tepung daun Senduduk dengan level 3,5\%.

Menurut pernyataan Medicastore (2003) yang dikutip oleh Mustikaningsih (2010), kadar LDL darah pada unggas kurang dari $150 \mathrm{mg} / \mathrm{dl}$. Fita (2007) menyatakan bahwa kadar LDL darah pada unggas berkisar 35,40-62,07 mg/dl. Berdasarkan pendapat tersebut, maka kadar LDL dari hasil penelitian ini tergolong baik.

\section{Kadar HDL-c (Hight-density lipoprotein cholestrol)}

Hasil analisis sidik ragam menunjukkan bahwa pemberian tepung daun Senduduk (Melastoma malabathricum L.) dalam ransum berpengaruh tidak nyata $(\mathrm{P}>0.05)$ terhadap kadar HDL-c darah ayam buras. Rataan kadar HDL darah ayam buras yaitu T0, T1, T2, T3 dan T4 berturut-turut sebesar $56,00 \mathrm{mg} / \mathrm{dl}, 59,5 \mathrm{mg} / \mathrm{dl}, 59,5 \mathrm{mg} / \mathrm{dl}$, $58,75 \mathrm{mg} / \mathrm{dl}, 56,25 \mathrm{mg} / \mathrm{dl}$. Kadar HDL pada 
penelitian ini sedikit lebih tinggi jika dibandingkan dengan hasil penelitian yang dilakukan oleh Suryo et al. (2012) yang menunjukkan HDL berkisar 40,5-50,4 mg/dl. Menurut Medicastore (2003) yang dikutip oleh Mustikaningsih (2010) hasil penelitian kadar HDL pada unggas yang baik adalah lebih dari $60 \mathrm{mg} / \mathrm{dl}$. Berdasarkan pendapat tersebut, maka kadar HDL dari hasil penelitian ini masih dalam kisaran normal.

Menurut Hartini dan Okid (2009) yang menyatakan bahwa kadar HDL yang tinggi mencegah tejadinya risiko aterosklerosis dengan cara mengangkut kolesterol dari jaringan perifer menuju hepar dan mengurangi kolesterol yang berlebihan. Menurut Murray et al. (2012) menyatakan bahwa HDL merupakan lipoprotein yang mengangkut lipid dari perifer menuju ke hepar. Molekul HDL relatif kecil dibandingkan lipoprotein lain, sehingga dapat melewati sel endotel vaskular dan masuk ke dalam intima untuk mengangkut kembali kolesterol yang terkumpul dalam makrofag. Selain itu, HDL juga mempunyai sifat antioksidan sehingga dapat mencegah terjadinya oksidasi LDL. Kadar HDL dipengaruhi oleh lingkungan dan genetik, antara lain pakan yang diberikan. Menurut Hartini dan Okid (2009) fungsi HDL adalah mengangkut kolesterol dari jaringan perifer menuju ke hepar, menyingkirkan kolesterol yang berlebihan dan menghambat perkembangan plak ateroma, sehingga kenaikan kadar HDL dalam darah akan mencegah terjadinya resiko aterosklerosis.

\section{Kadar VLDL- c (Very-Low-density lipoprotein cholestrol)}

Hasil analisis sidik ragam menunjukkan bahwa pemberian tepung daun Senduduk (Melastoma malabathricum L.) dalam ransum berpengaruh tidak nyata $(\mathrm{P}>0.05)$ terhadap kadar VLDL-c darah ayam buras. Rataan kadar VLDL darah ayam buras yaitu T0, T1, T2, T3 dan T4 berturutturut sebesar 25,00 mg/dl, 19,00 mg/dl, 18,50 $\mathrm{mg} / \mathrm{dl}, 18,50 \mathrm{mg} / \mathrm{dl}, 19,50 \mathrm{mg} / \mathrm{dl}$. Semakin turun kadar VLDL maka semakin bagus. VLDL merupakan lipoprotein dengan densitas yang sangat rendah yang terutama terdiri atas trigliserida (Almatsier, 2004). VLDL yang terbentuk di hati akan mengangkut trigliserida yang terbentuk dari asam lemak dan karbohidrat ke jaringan ekstra hati. Setelah sebagian besar trigliserida dikeluarkan oleh kerja lipoprotein lipase, VLDL ini menjadi IDL. IDL menyerahkan fosfolipid dan melalui kerja enzim Lechitin Cholesterol Acyltransferase (LCAT) mengambil ester kolesteril yang terbentuk dari kolesterol di HDL. Sebagian IDL diserap oleh hati. IDL sisanya kemudian melepaskan lebih banyak trigliserida dan protein di sinusoid hati, dan menjadi LDL (Ganong, 2008).

\section{Kadar Index Aterogenik}

Hasil analisis sidik ragam menunjukkan bahwa pemberian tepung daun Senduduk (Melastoma malabathricum L.) dalam ransum berpengaruh nyata $(\mathrm{P}<0.05)$ terhadap indeks aterogenik. Hasil uji lanjut menunjukkan T0 berbeda nyata $(\mathrm{P}<0.05)$ dengan T1, T2, T3, dan T4. T1 tidak berbeda nyata $(\mathrm{P}>0.05)$ dengan $\mathrm{T} 2, \mathrm{~T} 3$, dan $\mathrm{T} 4$, tetapi berbeda nyata $(\mathrm{P}<0.05)$ terhadap $\mathrm{T} 0$. Rataan kadar index aterogenik pada perlakuan T0 sampai T4 berkisar antara $(0,94$ $\mathrm{mg} / \mathrm{dl}$ - 1,29 mg/dl). Pada perlakuan T0 tanpa menggunakan tepung daun Senduduk (Melastoma malabathricum L.) menunjukkan kadar index aterogenik yang tinggi yakni sebesar $1,29 \mathrm{mg} / \mathrm{dl}$. Perlakuan T1 terjadi penurunan sebesar $21,7 \%$ yakni dengan kadar index sebesar 1,01 mg/dl. Pada perlakuan T2 terjadi penurunan sebesar 2,9\% dengan kadar index sebesar $0,98 \mathrm{mg} / \mathrm{dl}$. Pada perlakuan T3 terjadi penurunan sebesar $4,1 \%$ dengan kadar index sebesar $0,94 \mathrm{mg} / \mathrm{dl}$, dengan demikian perlakuan dalam penurunan kadar index aterogenik yang terkecil yakni pada perlakuan ke tiga (T3) dengan menggunakan tepung daun Senduduk pada level 3,5\%. Hal ini menunjukkan bahwa pemberian tepung daun Senduduk (Melastoma malabathricum L.) memberikan respon positif yang dapat menurunkan kadar index ayam buras.

Indeks aterogenik mengindikasi besarnya potensi terjadinya aterosklerosis 
(Prangdimurti et al., 2007). Semakin tinggi indeks aterogenik, maka potensi terjadinya aterosklerosis juga semakin tinggi. Index aterogenik akan tinggi apabila kadar kolesterol total serum tinggi dan HDLkolesterol rendah, sedangkan apabila kadar kolesterol total serum rendah dan HDLkolesterol tinggi maka indeks aterogeniknya rendah.

\section{Persentase Berat Organ Dalam}

Persentase berat organ dalam (hati, jantung, limpa, gizzard, usus dan panjang usus) pada masing-masing perlakuan selama penelitian dapat dilihat pada Tabel 4 .

\section{Persentase Berat Hati}

Hasil analisis sidik ragam menunjukkan bahwa pemberian tepung daun Senduduk (Melastoma malabathricum L.) dalam ransum berpengaruh tidak nyata $(\mathrm{P}>0.05)$ terhadap persentase berat hati ayam buras. Rataan persentase berat hati ayam buras yaitu T0, T1, T2, T3 dan T4 berturutturut sebesar $1,76 \%, 1,78 \%, 1,81 \%, 2,15 \%$, $1,85 \%$. Persentase berat hati pada penelitian ini hampir sama dengan Karetinah (1990) yang melaporkan bahwa persentase berat hati terhadap ayam kampung berumur 6 minggu sekitar 2,7\%. Berdasarkan pendapat tersebut, persentase berat hati pada penelitian ini termasuk pada kisaran normal dan tidak terlihat adanya kelainan fisik pada hati, menurut Rahayu (2010) kasus FLS (fatty liver Syndrome) ditandai dengan adanya akumulasi lemak dalam jumlah besar pada rongga perut dan organ-organ visceral, ukuran hati lebih besar dari ukuran normal, lemak secara ekstrim meluas di permukaan hati dengan ukuran dan warna bervariasi.

Menurut Yuwanta (2004), hati mensekresikan getah empedu yang disalurkan ke dalam duodenum. Fungsi getah empedu adalah menetralkan asam lambung $(\mathrm{HCl})$ dan membentuk sabun terlarut (soluble soaps) dengan asam lemak bebas. Kedua fungsi tersebut akan membantu absorpsi dan translokasi asam lemak. Dalam getah empedu yang mempunyai peranan penting, yaitu asam tarokholik dan glikokholik. Fungsi asam empedu adalah membantu digesti lemak dengan membentuk emulsi, mengaktifkan lipase pankreas, membantu penyerapan asam lemak, kolesterol, dan vitamin yang larut dalam lemak, stimulasi aliran getah empedu dari hati, dan menangkap kolesterol dalam getah empedu. Whittow (2000) menambahkan bahwa besar dan berat hati dipengaruhi oleh beberapa faktor seperti jenis hewan, besar tubuh, genetik serta makanan. Fungsi hati sebagai tempat utama untuk pencernaan dan penyerapan lemak melalui produksi getah empedu yang mengandung kolesterol serta garam-garam empedu yang disintesis dalam hati (Murray et al., 2003).

Tabel 4. Persentase berat organ dalam ayam buras dengan pemberian tepung daun Senduduk (Melastoma malabathricum L.)

\begin{tabular}{lcccccc}
\hline \multirow{2}{*}{ Parameter } & \multicolumn{7}{c}{ Perlakuan } & \multirow{2}{*}{ Ket. } \\
\cline { 2 - 6 } & T0 & T1 & T2 & T3 & T4 \\
\hline Berat hati (\%) & $1,76 \pm 0,34$ & $1,78 \pm 0,18$ & $1,81 \pm 0,23$ & $2,15 \pm 0,37$ & $1,85 \pm 0,24$ & ns \\
Berat jantung (\%) & $0,39 \pm 0,05$ & $0,39 \pm 0,04$ & $0,39 \pm 0,06$ & $0,37 \pm 0,02$ & $0,41 \pm 0,05$ & $\mathrm{~ns}$ \\
Berat limfa (\%) & $0,33 \pm 0,18$ & $0,35 \pm 0,15$ & $0,34 \pm 0,23$ & $0,39 \pm 0,18$ & $0,41 \pm 0,18$ & $\mathrm{~ns}$ \\
Berat gizzard (\%) & $2,55 \pm 0,38$ & $2,62 \pm 0,42$ & $2,43 \pm 0,42$ & $2,27 \pm 0,26$ & $2,51 \pm 0,41$ & $\mathrm{~ns}$ \\
Berat usus (\%) & $3,13 \pm 0,32$ & $3,25 \pm 0,07$ & $4,00 \pm 0,42$ & $3,61 \pm 0,48$ & $3,52 \pm 0,52$ & $\mathrm{~ns}$ \\
Panjang usus (cm) & $126,50 \pm 4,04$ & $135,88 \pm 1,03$ & $135,88 \pm 1,03$ & $133,75 \pm 7,50$ & $124,00 \pm 4,61$ & $\mathrm{~ns}$ \\
\hline Keterangan: T0: Pemberian 0\% Tepung Daun Senduduk; T1: Pemberian 1,5\% Tepung Daun Senduduk; \\
T2:Pemberian 2,5\% Tepung Daun Senduduk; T3: Pemberian 3,5\% Tepung Daun Senduduk; T4: Pemberian \\
4,5\% Tepung Daun Senduduk; ns: non signifikan
\end{tabular}




\section{Persentase Berat Jantung}

Hasil analisis sidik ragam menunjukkan bahwa pemberian tepung daun Senduduk (Melastoma malabathricum L.) dalam ransum berpengaruh tidak nyata $(\mathrm{P}>0.05)$ terhadap persentase berat jantung ayam buras. Rataan persentase berat jantung ayam buras yaitu T0, T1, T2, T3 dan T4 berturut-turut sebesar $0,39 \%, 0,39 \%, 0,39 \%$, $0,37 \%, 0,41 \%$. Rataan persentase bobot jantung ayam buras dari semua perlakuan dalam penelitian ini tidak jauh berbeda dengan laporan Putnam (1991) berat jantung berkisar antara $0,42-0,70 \%$.

Menurut Ressang (1984) jantung unggas relatif besar, besar jantung tergantung pada jenis, umur, besar dan pekerjaan hewan. Persentase berat jantung pada penelitian ini termasuk pada kisaran normal dan tidak terlihat adanya kelainan fisik pada jantung. Hal tersebut memberikan indikasi bahwa ransum yang diberikan tidak mengakibatkan kelainan metabolisme yang mempengaruhi ukuran dan kondisi jantung. Fungsi jantung adalah sebagai pemompa darah dalam sistem sirkulasi atau transportasi tubuh pembesaran jantung dapat terjadi bila ada akumulasi racun pada otot jantung.

\section{Persentase Berat Limpa}

Limpa merupakan organ tubuh yang kompleks dengan banyak fungsi. Fungsi limpa sebagai tempat penyimpan sel-sel darah merah dan darah putih dalam sirkulasi yang normal (Nesheim et al., 1979). Beberapa fungsi limpa yaitu untuk menyimpan darah, bersama hati dan sumsum tulang belakang berperan dalam pembinasaan eritrosit-eritrosit tua, metabolisme nitrogen terutama pembentukan asam urat serta membentuk limfosit yang berhubungan dengan pembentukan antibodi (Dwipayanti, 2008).

Hasil analisis sidik ragam menunjukkan bahwa pemberian tepung daun Senduduk (Melastoma malabathricum L.) dalam ransum berpengaruh tidak nyata $(\mathrm{P}>0.05)$ terhadap persentase berat limpa. Rataan persentase berat limpa ayam buras yaitu T0, T1, T2, T3 dan T4 berturut-turut sebesar $\quad 0,33 \%, \quad 0,35 \%, \quad 0,34 \%, \quad 0,39 \%$, $0,41 \%$. Persentase berat limpa pada penelitian ini lebih tinggi jika dibandingkan dengan hasil penelitian yang dilakukan oleh Herawati (1985) yang menyatakan bahwa persentase berat limpa berkisar $0,11-0,16 \%$. Bobot limpa menunjukkan tidak nyata dipengaruhi oleh perlakuan ransum yang diberikan bahwa fungsi limpa sebagai tempat penyimpan sel-sel darah merah dan darah putih dalam sirkulasi yang normal. Menurut Ganong (1979), bobot limpa bervariasi sejalan dengan meningkatnya bobot tubuh dan volume darah.

\section{Persentase Berat Gizzard}

Hasil analisis sidik ragam menunjukkan bahwa pemberian tepung daun Senduduk (Melastoma malabathricum L.) dalam ransum berpengaruh tidak nyata $(\mathrm{P}>0.05)$ terhadap persentase berat gizzard ayam buras. Rataan persentase berat gizzard ayam buras yaitu T0, T1, T2, T3 dan T4 berturut-turut sebesar 2,55\%, 2,62\%, 2,43\%, $2,27 \%, 2,51 \%$. Pada penelitian ini persentase berat gizzard masih dalam kisaran yang normal yaitu 2,43-2,62\%. Penelitian tidak jauh berbeda dengan menurut Sturkie (2000) yang menyatakan bahwa kisaran normal persentase berat gizzard dengan nilai 1,6 2,3\% dari bobot hidup.

Menurut Usman (2010), peningkatan bobot gizzard disebabkan karena peningkatan serat dalam pakan. Hal ini mengakibatkan beban gizzard lebih besar untuk memperkecil ukuran partikel ransum secara fisik, akibatnya urat daging gizzard tersebut akan lebih tebal sehingga memperbesar ukuran gizzard. Hal tersebut tidak mempengaruhi fungsi lain dari gizzard. Gizzard disebut juga muscular stomach (perut otot) atau empedal. Lokasinya berada diantara ventriculus dan bagian atas usus halus. Fungsi utama empedal adalah melumatkan pakan dan mencampur dengan air menjadi pasta yang dinamakan chymne. Ukuran dan kekuatan empedal dipengaruhi oleh kebiasaan makan ayam tersebut. Ayam yang dipelihara empedalnya lebih kuat dari pada ayam yang dikurung (Yuwanta, 2004). Menurut Rosyani 
(2013), ukuran gizzard mudah berubah bergantung pada jenis makanan yang biasa dimakan oleh unggas tersebut. Ukuran gizzard juga dapat dipengaruhi oleh tingkat konsumsi ransum, karena konsumsi ransum yang tinggi dapat mengakibatkan penebalan pada urat daging gizzard, sehingga ukuran gizzard pun akan semakin besar.

\section{Persentase Berat Usus}

Hasil analisis sidik ragam menunjukkan bahwa pemberian tepung daun Senduduk (Melastoma malabathricum L.) dalam ransum berpengaruh tidak nyata $(\mathrm{P}>0.05)$ terhadap persentase berat usus. Rataan persentase berat usus ayam buras yaitu T0, T1, T2, T3 dan T4 berturut-turut sebesar $3,13 \%, \quad 3,25 \%, \quad 4,00 \%, 3,61 \%$, $3,52 \%$. Rataan kadar berat usus pada penelitian ini berkisar 3,12-4,00\%. Rataan persentase bobot usus dari hasil penelitian ini lebih rendah dengan yang dilaporkan oleh Resnawati (1986), bahwa usus ayam berkisar antara 4,01-4,89\%. Hal ini berarti bahwa pemberian tepung daun Senduduk (Melastoma malabathricum L.) tidak mengganggu fungsi penyerapan dan transportasi zat-zat nutrisi pada usus, sehingga perkembangan organ dalam keadaan seimbang dengan meningkatnya laju pertumbuhan. Strurkie (1976), menyatakan bahwa bobot usus halus bervariasi tergantung pada jenis hewan dan kebiasaan makan.

\section{Panjang Usus}

Hasil analisis sidik ragam menunjukkan bahwa pemberian tepung daun Senduduk (Melastoma malabathricum L.) dalam ransum berpengaruh tidak nyata $(\mathrm{P}>0.05)$ terhadap panjang usus ayam buras. Rataan panjang usus ayam buras yaitu T0, T1, T2, T3 dan T4 berturut-turut sebesar $126,50 \mathrm{~cm}, 135,88 \mathrm{~cm}, 135,88 \mathrm{~cm}, 133,75$ $\mathrm{cm}, 124,00 \mathrm{~cm}$. Rataan persentase panjang usus ayam buras dalam penelitian ini berkisar $124 \mathrm{~cm}-135,88 \mathrm{~cm}$. Semakin panjang usus maka perkembangan folikel semakin bagus sehingga terjadi penyerapan-penyerapan usus dengan besarnya usus dalam penyerapan usus dapat lebih banyak. Hal ini disebabkan karena kemampuan penyerapan nutrisi ransum tidak terdapat perbedaan, sehingga panjang usus tidak berbeda nyata, jika konsumsi pakan meningkat maka panjang usus halus mengalami perluasan permukaan karena kinerja usus akan mengalami peningkatan pada proses absorpsi nutrisi pada pakan. Dalam proses penyerapan ransum peran usus halus sangat penting dalam penyerapan nutrisi pada permukaan vili usus halus.

Performans vili usus dipengaruhi oleh beberapa faktor antara lain jenis zat pakan, zat kimia pakan dan zat feed additive. Hal ini sesuai dengan pendapat Retnoadiati (2001) yang menyatakan bahwa ransum yang memerlukan penyerapan secara intensif maka usus akan memperluas permukaannya dengan mempertebal dinding usus atau memperpanjang usus sehingga banyak nutrisi yang diserap oleh usus. Hermana dan Aliyani (2003) menambahkan bahwa panjang usus pada ayam yang diberi pakan dengan serat kasar tinggi menyebabkan protein sulit didegradasi, sehingga panjang usus halus lebih panjang dibandingkan dengan pakan dengan serat kasar rendah.

\section{KESIMPULAN}

Berdasarkan hasil penelitian dapat disimpulkan bahwa pemberian tepung daun Senduduk (Melastoma malabathricum L.) dalam ransum pada level 4,5\% menurunkan kadar kolesterol, kadar LDL-c, kadar index, tetapi tidak menurunkan kadar trigliserida, kadar HDL-c, kadar VLDL, dan juga tidak menaikkan persentase berat usus, panjang usus, dan tidak menaikkan persentase berat hati, jantung, limpa, gizzard.

\section{UCAPAN TERIMAKASIH}

Terimakasih disampaikan kepada kemristekdikti yang telah mendanai seluruh penelitian ini melalui Program Kreativitas Mahasiswa (PKM) tahun 2017. Terimakasih juga disampaikan kepada Prof. Dr. Ir. Yosi Fenita, MP yang telah membimbing dalam kegiatan penelitian ini. 


\section{DAFTAR PUSTAKA}

Afrianti, M.B. Dwiloka, dan B.E. Setiani. 2013. Perubahan Warna, Profil Protein, dan Mutu Organoleptik Daging Ayam Broiler setelah Direndam dengan Ekstrak Daun Senduduk. Jurnal Aplikasi Teknologi Pangan. 2(3): 116 - 120.

Almatsier, S. 2004. Prinsip Dasar Ilmu Gizi. Jakarta: PT. Gramedia Pustaka Utama.

Bintang, I. A. K dan S. N, Jarmani. 2012. Penggunaan Kencur (Kaempferia galanga L). Bawang Putih (Allium sativum L) dan Kombinasi dalam Pakan Broiler. Lokakarya Nasional Inovasi Teknologi dalam Mendukung Usaha Ternak Unggas Berdaya Saing.

Direktorat Jenderal Peternakan. 2001. Kebijakan pengembangan agribisnis unggas air di Indonesia. Makalah Lokakarya Nasional Unggas Air; Bogor, 6-7 Agustus 2001. Fakultas Peternakan-IPB kerjasama dengan Balai Penelitian TernakPuslitbangnak. Bogor.

Direktorat Jenderal Peternakan dan Kesehatan Hewan. 2017. Statistik Peternakan dan Kesehatan Hewan. Kementerian Pertanian.

Direktorat Pakan. 2014. Pelanggaran Penggunaan Hormon Tertentu dan/atau Antibiotik sebagai Imbuhan Pakan. Jakarta: Direktorat Jenderal Peternakan dan Kesehatan Hewan Kementerian Pertanian Indonesia.

Dwipayanti N. M. Y. 2008. Profil organ dalam serta histopatologi usus dan hati ayam kampung terinfeksi cacing Ascaridia galli yang diberi tepung daun jarak (Jathropa curcas 1.). (Skripsi). Fakultas Pertanian IPB. Bogor.

Fita, M. 2007. Pengaruh Pemberian Ekstrak Temulawak dan Ekstrak Kunyit Melalui Air Minum terhadap Kadar
HDL dan LDL Darah Ayam Broiler. Tesis. Universitas Jendral Sudirman. Purwokerto.

Ganong, W. F. 1979. Fisiologi Kedokteran. Terjemahan Reviewof Medical Phisiology. CV EGG Jakarta.

Ganong, W. F. 2008. Buku Ajar Fisiologi Kedokteran Edisi 22. Jakarta: EGC

Hartadi, H.,S. Reksohadiprodjo dan A. D. Tilman. 2005. Tabel Komposisi Pakan untuk Indonesia. Gadjah Mada University Press. Yogyakarta.

Hartini, M. dan P.A. Okid. 2009. Kadar kolesterol darah tikus putih (Rattus norvegicus) hiperkolesterolemik setelah perlakun VCO. Bioteknologi. 6(2):55-62.

Herawati, L. 1985. Pengaruh Pemberian Probiotikum dalam Ransum Ayam Pedaging Terhadap Beberapa Organ Tubuh. Karya Ilmiah. Fakultas Peternakan Institut Pertanian Bogor, Bogor.

Hermana S.W. dan A. Aliyani. 2003. Persentase bobot karkas dan organ dalam ayam broiler yang diberi tepung daun talas (Colocasia esculenta) dalam ransum. Media Peternakan 26: 1-10.

Karetinah, D. P. 1990. Perbandingan karkas dan non karkas pada ayam jantan kampung petelur dan broiler umur 6 minggu. Skripsi. Fakultas Peternakan. Institut Pertanian Bogor.

Metwally, M. A. A., A. M. El-Gellal., and S. M. El-Sawaisi, S. M., 2009, Effect of Silymarin on Lipid Metabolism in Rats, World Appl. Sci. J., 6 (12): 1634-1637.

Murray, R. K., D. K. Granner, P. A. Mayes and V. W. Rodwell. 2003. Biokimia Harper. Edisi 25. Terjemahan: dr. Andry. H. Penerbit Buku Kedokteran EGC. Jakarta. 148, 275.

Murray, R. K., D. A. Bender, K.M. Bothan, P.J. Kennelly, P.A Weil, and V.W. 
Rodwell. 2012. Harper's Illustrated Biochemistry. The Mc Graw-Hill Companies. Inc. USA

Mustikaningsih, F. 2010. Pengaruh Pemberian Berbagai Level Ekstrak Kunyit terhadap Kadar Kolesterol, High Density Lipoprotein dan Low Density Lipoprotein dalam Darah pada Ayam Broiler. Skripsi. Fakultas Peternakan Universitas Diponegoro, Semarang.

Nesheim, M.C., E.A. Richard and E.C. Leslie. 1979. Poultry Production. 12nd Ed. Leaand Febiger. Philadelphia.

Putnam, P. A. 1991. Handbook of Animal Science. Academic Press, San Diego.

Prangdimurti, E., N. S. Palupi dan F. R. Zakaria. 2007. Metode Evaluasi Nilai Biologis Karbohidrat dan Lemak. Modul e-Learning ENBP, Departemen Ilmu dan Teknologi Pangan-Fatepa-IPB.

Priyanti, A., A.R. Setioko, Y. Yusdja dan R.A. Saptati. 2005. Prospek dan arah pengembangan agribisnis ternak unggas. Badan Penelitian dan Pengembangan Pertanian. Departemen Pertanian. Jakarta.

Rahayu, D. I. 2010. Sindrom Hati Berlemak pada Ayam Petelur. http://imbang.staff.umm.ac.id/?p=147 - 2010. Diakses pada tanggal 18 agustus 2018.

Rasyid, T. G. 2002. Analisis perbandingan keuntungan peternak ayam buras dengan system pemeliharaan yang berbeda. Bulletin Nutrisi dan Makanan Ternak 3(1).

Ressang, A. A. 1984. Patologi Khusus Veteriner. Gadjah Mada University Press, Yogyakart
Resnawati, H. 1986. Pemanfaatan Biji Saga Pohon (Adenanthera pavonina L.) sebagai Bahan Makanan dalam Ransum Ayam Pedaging. Disertasi. IPB, Bogor.

Retnoadiati, N. 2001. Persentase bobot karkas, organ dalam dan lemak abdominal ayam broiler yang diberi ransum berbahan baku tepung kadal (Mabouya multifaciata Kuhl). Skripsi. Fakultas Peternakan. Institut Pertanian Bogor, Bogor.

Rosyani, S. 2013. Pemberian Pakan Konsentrat Mengandung Tepung Inti Sawit yang Ditambahkan Pollard atau Dedak dan Pengaruhnya terhadap Persentase Organ Dalam Ayam Broiler. Skripsi. Institut Pertanian Bogor. Bogor.

Santoso, U. dan W. Piliang. 2004. Penggunaan ekstrak daun katuk sebagai feed additive untuk memproduksi meat designer. Laporan Penelitian. Universitas Bengkulu. Bengkulu.

Terao, J., K. Yoshichika, M. Kaeko. 2008. Vegetable flavonoids and cardiovascular disease. Asia Pac. J. Clin. Nutr. 17: 291-293.

Usman, A. N. R. 2010. Pertumbuhan Ayam Broiler (Melalui Sistem Pencernannya) yang Diberi Pakan Nabati dan Komersial dengan Penambahan Dysapro. Institut Pertanian Bogor. Bogor.

Whittow, G. 2000. Strurkie's Avian Physiology. Fifth edition. Academic Press USA

Yuwanta, T. 2004. Dasar Ternak Unggas. Kanisius. Yogyakarta. 